\title{
Spatial and Economy Dynamics Analysis After 1'st Bali Bombing at Kuta, Bali
}

\author{
Putu Giana Eka Suardi ${ }^{1}$, I Gede Adnya Ariyusa ${ }^{2}$ \\ ${ }^{1}$ Faculty Of Geography Universitas Gadjah Mada \\ ${ }^{2}$ Faculty of Economics and Bussiness, Universitas Gadjah Mada
}

\begin{abstract}
Terrorism means the use of violence of political ends and includes any use of violence for the purpose putting the public or any section of the public in fear. Terrorists often use threats to create fear among the public, to convince citizens that government is powerless to prevent terrorism, and to get immediate publicity for their causes.the real case of terorism that indonesia had expereinced on of them was first bali bombing. After the incident.the goverment attempted the recovery process. Contoh nyata dari bentuk terorisme yang dialami di Indonesia adalah peledakan bom Bali 1 di Legian,Kuta, Bali . On Saturday, 12 October, 2002. Setelah kejadian, pemerintah mengupayakan proses recovery. ). The Recovery success can be evaluated by looking at spatial and economy dynamics. the Spatial dynamycs are represented by the development of build up area. Build up area represents public facility. Built up area can be done using algorithm NDBI (Normalized Difference Built Up Index) while economy dynamics represented by stock index price. The related research about spatial and economy conditiaon after terror bomb in bali is able to give an overview about the rate of recovery success after bali bombing. This research uses either primary and secondary data. Primary data consist s of Landsat 8 OLI of Bali Province from November 2002 until January 2003 . Secondary data consists of stock index price data of LQ45 from September 2002 to January 2003 . Sattelite image processed using algorithm NDBI and GIS to provide size of build area in Kuta, Bali, while index price processed using descriptive statistic methods. From this process, we get result that Overall built up area changing 37 percent from November 2002,but changing mostly happen from November to December. From November to December 2002, built up area increases about $42 \%$. While, from price index show cement sector will recover rapidly along recovery process in Kuta,Bali.After all the price index recovery data are processed using average analysis.It shows that most of the data recover in one month. Index price recovery, was parallel with facility development.From those fact, we can conclude recovery effort in Kuta,Bali, could affect spatial and economic condition .
\end{abstract}

Keywords: Spatial, economy, Dynamics, Recovery, Bali Bombing

\section{Introduction}

Terrorism means the use of violence of political ends and includes any use of violence for the purpose putting the public or any section of the public in fear. Terrorists often use threats to create fear among the public, to convince citizens that government is powerless to prevent terrorism, and to get immediate publicity for their causes. Weapons of mass destruction (WMD), including incendiary, explosive, chemical, biological, radiological, and nuclear agents, have the capability to cause death or serious bodily injury to a significant number of people, thus posing the threat of a catastrophic incident. Terrorism includes the following hazards: conventional bomb, biological agent, chemical agent, nuclear bomb radiological agent arson/incendiary attack armed attack, agriterrorism, intentional hazardous materials release ,assaults on the infrastructure and electronic information systems that could result in consequences affecting human life, health and safety. (Guadalope Basin River Authority,2005). The Federal Bureau of Investigation (FBI) categorizes terrorism to two types consist of domestic and International terrorism .Domestic terrorism is terrorist activities that focus on facilities or populations without foreign direction. International Terrorism is terrorist activities that are foreign-based and/or sponsored by organizations or groups outside the country real case of terorism that indonesia had expereinced one of them was bomb terror I or Bom bali 1. in Bali. After the incident.the goverment attempted the recovery process. The first Bali bombing in Legian,Kuta, Bali . On Saturday, 12 October, 2002, at 23:08 hours, two bombs detonated within a short period of time on the Indonesian island of Bali. The explosions occurred at two nightclubs situated along the main street in the holiday resort of Kuta Beach. The first, smaller charge was concealed in a vest worn by a so-called suicide bomber who entered Paddy's Bar, a two-storey structure of about 500 square meters. The second charge was in a Mitsubishi L300 
minivan that blocked the traffic on the one-way street outside the Sari Club. The nightclub was situated on the same street as Paddy's Bar but on the opposite side, about 1521 meters away. The explosions claimed 202 lives and more than 300 persons were injured. Most of the dead and injured were tourists from 21 different countries (The Committee for Disaster Medicine Studies,2007). After the incident, the goverment attempted the recovery process mengupayakan proses recovery.. The Bali Recovery Group and other administrators (2004) oversaw the provision of such support included medical treatment, financial aid, psychological counselling, food and accommodation. There was a high degree of consensus between government, NGOs, private enterprise and the local community that such assistance remained a relief priority (Gurtner,2004). Recovery success can be evaluated by looking at spatial and economy dynamics. Spatial dynamycs are represented by the development of build up area. Build up area represent public facility. Built up area can be done using algorithm NDBI (Normalized Difference Built Up Index) while economy dynamics represented by stock index price. The indirect costs of terrorism can be significant and have the potential to affect the economy in the medium term by undermining consumer and investor confidence. A deterioration of confidence associated with an attack can reduce the incentive to spend as opposed to save, a process that can spread through the economy and the rest of the world through normal business cycle and trade channels (IMF,2001). The investor trust will restore if the recovery process is a success, then it will affect the stock index price The related research about spatial and economy conditiaon after terror bomb in bali is able to give an overview about the rate of recovery success aftrer terror bomb in bali

\section{Methods}

This research uses either primary and secondary data. Primary data consist s of Landsat 8 OLI of Bali Province from November 2002 until January 2003 . Secondary data consists of stock index price data of LQ45 from September 2002 to January 2003 .

\section{Data Processing}

Landsat 8 OLI processed using NDBI algorithm. NDBI algorithm show existence of built up area by compare difference between infrared band and red band, with addition of thus band. Image that has been proceed to NBDI then combine with intersect method. The intercet performed by software arcmap to show the built up area from november 2002 until january 2003. Proportion of built up area calculated by geometry method.

\section{Result And Discussion}

Recovery effort after Bali bombing in 2002 can be evaluated by looking at spatial and economy dynamic. Spatial dynamic represent by dynamic of built up area. Dynamic of built up area can be seen by using integration between remote sensing and GIS (Geographic Information System) methods.From NDBI algorithm, difference between built up and non built up area can clearly separated. After data processed using NDBI to show changing process of built up area from November 2002 untill January 2003. Image from October 2002 can't be included, because too many noise such as cloud on the image.Those image then processed using Calculate geometry to find size of changing area every month. Result from calculate geometry represent using bar diagram like diagram 1 below. Overall built up area changing 37 percent from November 2002,but changing mostly happen from November to December. From November to December 2002, built up area increase about $42 \%$.

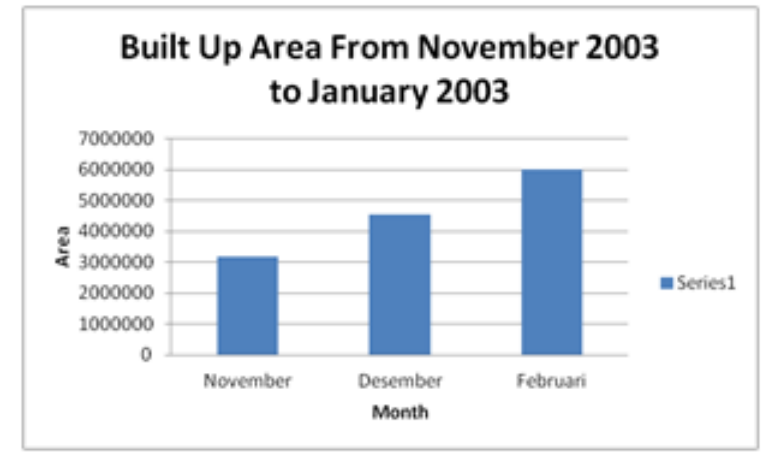

Diagram 1. Built Up Area Dynamics From November 2002 Until January 2003. 
The Impact of recovery not only show from spatial dynamics but also economy dynamic. Economy dynamic can be seen from stock index price. Stock index price analysis uses historical price of corporation that listed in LQ45 . LQ45 was used, because thus companies have good financial conditions, prospect of growth, high transaction value and frequency. From 45 companies in LQ45, only 20 companies that have complete historical price data . After descriptive statistic analysis, obtained some result such as below.

First, data show that there are five companies, with highest price decrease. This five companies consist of 2 cement sector industry, 1 bank sector, 1 tobacco company and one retail company. Cement company has a strong relation to terrorism. ISIL (Islamic State in Iraq and the Levant) report notes that ISIL has control over five major cement plants in Syria and Iraq: Al-Raqqah Guris Cement Plant located in Raqqa, Syria; and the AlFallujah, Kubaisa, and Al-Qaim plants in Iraq.Based on those fact, after Bali bombing occur, there were degradation of investor trust. This fact occur, because there was sentiment, consider cement industry was important sector for AL-Qaeda financial.

The second one is banking sector.Bali bombing has destroyed some public facilities. This condition brought Indonesia to unstable financial condition. Unstable financial condition can bring same impact to bank sector, remind bank include in financial system. The other sectors that show high decrease on stock price index are tobacco and retail sector.Just like cement sector, tobacco industry has strong role in terrorist organization. The increasing use of smuggled tobacco by terrorist and insurgent groups parallels the rapid growth of a multibilliondollar trade in cigarette smuggling around the world. Huge tobacco black markets have arisen from New York State to Paraguay to Eastern Europe, as smugglers move cheap and counterfeit cigarettes to sell in lucrative high-tax regions. The illicit trade is fueling addiction, say health experts, by making inexpensive cigarettes wide ly available, while robbing governments of sorely needed tax revenue. At the same time, officials warn, the booming black markets are fueling not only some terrorist groups but dozens of organized crime gangs, who find the big profits and low risk hard to resist.

In addition to al-Qaeda in the Islamic Magreb, at least a half-dozen terrorist groups and insurgencies have profited from the black market in tobacco. Among the others (Wilson,2009).Terrorism attact at Kuta increase investor sentiment on tobacco industry. There was fear that tobacco industry in Indonesia involve in tobacco black market.

The last one is retail sector. Terorist attact in Kuta,Bali absolutely affect visitor amount to Bali. Afetr Bali bombing, visitors have reportedly been deserting tourist sites in other parts of Indonesia since the Bali events (Department of the Parliamentary Library, 2002). Retail sector has strong relation with visitor rate. Tourist wheater domestic, or foreign are consumer of retail industry. Degradation of tourist visit rate will impact to retail sale rate. This condition give influence to investor trust.

Although highest price decrease show in cement industry, but cement sector is the fastest sector that reaches early price, just like graph 2 . After bombing event, there were many damages to public facilities. To construct public facility, many cement needed. Escalation of cement demand,will increase investor trust.

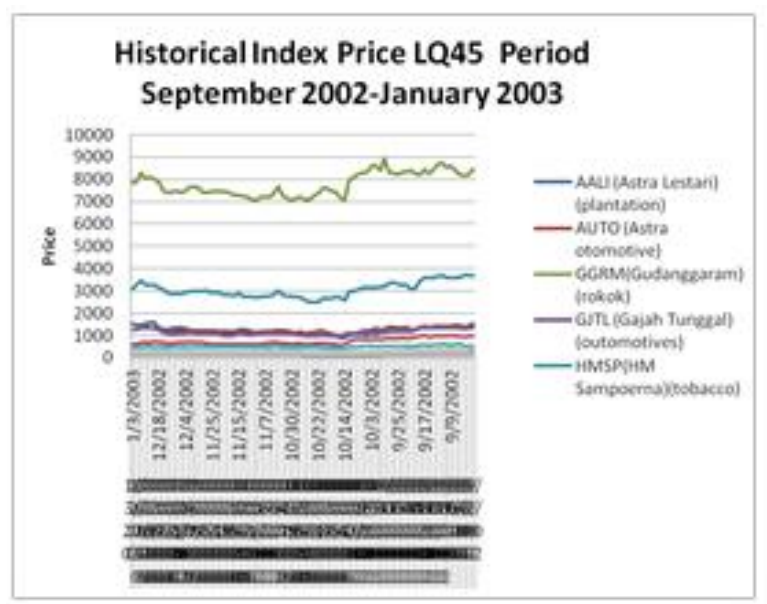

Graphic 2 . Historical Index Price LQ45 Period September 2002 Until January 2003 
Based on this statement, cement sector will recover rapidly along recovery process in Kuta,Bali.After all the price index recovery data are processed using average analysis.It show that most of the data recover in one month. Index price recovery, was parallel with facility development.From those fact, we can conclude recovery effort in Kuta ,Bali, could affect spatial and economic conditio

\section{Conclusion}

From this process, we get result that Overall built up area changing 37 percent from November 2002,but changing mostly happen from November to December. From November to December 2002, built up area increase about $42 \%$. While, from price index show cement sector will recover rapidly along recovery process in Kuta,Bali.After all the price index recovery data are processed using average analysis. It show that most of the data recover in one month. Index price recovery, was parallel with facility development.From those fact, we can conclude recovery effort in Kuta,Bali, could affect spatial and economic condition

\section{References}

[1] Guadalope Basin River Authority.(2005). The Guadalupe Basin Hazard Mitigation Action Plan (MAP).GRBA.Seguin

[2] The Committee for Disaster Medicine Studies.(2007). The Terror Attack on Bali, 2002 .Kamedo-report Volume 89.Socialstyrels en.Stockholm

[3] Johnson,Barry.2005. The Impact of Terrorism on Financial Markets.IMF.Washington.

[4] Gurtner,Yutte. (2004). The Australian Journal of Emergency Management.Volume.19 Number 4,page 59.

[5] Financial Action Task Force.2015. Financing of the Terrorist Organisation Islamic State in Iraq and the Levant (ISIL).Paris: FATF

[6] Wilson,Kate.2009.Terroris $m$ and tobacco:Extremists, insurgents turn cigarette,s muggling.https://www.publicintegrity.org. Access at 17 December 2016. 